\title{
The effects of dietary soyabean oil-cake meal on performance and gut histology of piglets
}

\author{
E. Pieterse ${ }^{\#}$, E.L. Gloy, and J. Viljoen \\ Agricultural Research Council, Animal Nutrition and Animal Products Institute, Private Bag X 2, Irene 0062, South Africa
}

\begin{abstract}
The effects of four diets containing different protein sources on the performance and gut histology of piglets were compared. The diets contained as the main protein sources either: milk powder plus fishmeal, milk powder plus high-protein ( $48 \%$ crude protein) soyabean oil-cake meal, fishmeal plus high-protein soyabean oil-cake meal or high-protein soyabean oil-cake meal alone. No differences $(p>0.05)$ were observed between treatments for average daily gain, feed conversion ratio, intake or intestinal villus height. It was concluded that high-protein soyabean oil-cake meal can be utilised successfully in diets for weaner pigs either in combination with other protein sources or as main protein source without detrimental effects on production parameters or gut histology. These results apply to diets are formulated on the basis of digestible amino acids using soyabean oil-cake meal has been correctly processed.
\end{abstract}

Keywords: Weaner, piglet, digestible amino acids, gut histology, soyabean oil-cake meal

* Author to whom correspondence should be addressed. E-mail: elsje@iapi1.agric.za

\section{Introduction}

There is a firm belief amongst some producers that piglets must be fed high levels of milk products in order to maximise growth rate and production. As some of these milk products are expensive, substitution with other protein sources such as high-protein soyabean oil-cake meal could reduce production costs. Weaning at 3-4 weeks exposes the piglet to nutritional, environmental and social stress that usually results in a post weaning lag-phase manifested as slow growth, scouring and general ill-thrift (Ravindran \& Kornegay, 1993). The piglet is also very vulnerable to infections during this period, since the immune and enzyme systems are still incompletely developed. The early weaning process creates an initial physiological situation requiring a particular nutrient form and balance in the feed (Seve, 1985). As a result, it is common practice to use milk products and pre-cooked starches in creep diets (Aherne \& Nielsen, 1982; Campbell \& Dunkin, 1983; Campbell \& Taverner, 1986; Campbell et al., 1988). It has also been well documented that growth rate and efficiency of feed utilisation of early-weaned piglets is appreciably better when milk proteins are used instead of soyabean proteins (Wilson \& Leibholz, 1981; Walker et al., 1986; Zijlstra et al., 1996). Weaning has also been shown to cause changes in the morphology of the small intestine (Miller et al., 1986; Van Beers-Schreurs et al., 1998). These changes include reduction of villus height, increased depth of the lamina propria, reduced disaccharidase concentrations and reduced absorption (Dunsford et al., 1989). The decrease in villus height may be caused by pathogens (Vellenga et al., 1992), antigens (Miller et al., 1986; Li et al., 1991) or reduced feed intake (Nunez et al., 1996; Pluske et al., 1996; Van BeersSchreurs et al., 1998).

Reduced performance in pigs fed soyabean protein has been associated with reduced digestibility of dietary amino acids (AA) (Wilson \& Leibholz, 1981; Leibholz, 1986; Viljoen \& Ras, 1989). Differences in ileal amino acid digestibility values between protein sources used to feed early-weaned piglets have been reported by several authors (Leibholz, 1985a; Leibholz, 1985b; Fan et al., 1995; Viljoen et al., 1998a). Feedstuff digestibility is influenced by aspects such as antinutritional factors (Sauer \& Ozimek, 1986; Huisman \& Jansman, 1991), inclusion levels (Viljoen et al., 1998b), post weaning feed intake which affects pancreatic development and thus enzyme activity (Makkink et al., 1994) and amino acid damage due to overheating during processing (Marty \& Chavez, 1995). Some of the above-mentioned aspects are intrinsic characteristics of the protein source under investigation. It was noted by Li et al. (1991) that conventionally processed commercial soyabean oil-cake meal may contain antigens that cause immunological responses in early-weaned pigs resulting in decreased villus height.

Results of Viljoen (1998) showed that weaner diets based on different protein sources can be utilised with equal efficiency (feed conversion) when balanced according to digestible amino acid content. However, it was found that differences in feed intake attributable to the use of protein sources of different origin resulted in differences in growth rates. The palatability of high-protein soyabean oil-cake meal could possibly obviate this problem. Zhang et al. (1985) compared simple, low cost diets without skim milk powder to a more complex and expensive basal diet containing $17.8 \%$ skimmedmilk powder, and reported similar food-to-gain ratios for the diets. The aims of this study were to determine whether high- 
protein soyabean oil-cake meal could be substituted for milk powder or fishmeal in weaner diets, and to determine the effects of this on the histology of the small intestine.

\section{Materials and methods}

Weaner piglets of a commercial crossbred strain were used. Eighty piglets (40 boars and 40 gilts) weaned at an age of 28 days with an average live mass of $6.5 \mathrm{~kg}$ were randomly allocated to four experimental diets ( 20 piglets, i.e. 10 boars and 10 gilts per treatment). Diets were formulated to contain, as the main protein sources, either milk powder (MP) and fish meal (FM) (Control; designated MP+FM), MP and high-protein soyabean oil-cake meal (HPS) (designated MP+HPS), FM and HPS (designated HPS + FM) or HPS alone (designated HPS) (Table 1).

Table 1 Composition of experimental diets $(\mathrm{kg} / 100 \mathrm{~kg}$ diet $)$

\begin{tabular}{lcccc}
\hline Ingredients $(\mathrm{kg})$ & $\mathrm{MP}^{*}+\mathrm{FM}^{* *}$ & $\mathrm{MP}^{*} \mathrm{HPS}^{* * *}$ & HPS + FM & HPS \\
\hline Maize meal & 65.11 & 65.80 & 71.31 & 70.13 \\
Soyabean oil-cake meal (48\% & - & 13.00 & 5.20 & 20.80 \\
crude protein) & & & & \\
Skimmed milk powder & 7.60 & 11.40 & - & - \\
Fishmeal & 9.80 & & 10.00 & - \\
Fine bran & 11.50 & 2.30 & 6.90 & - \\
Sunflower oil & 2.60 & 2.30 & 2.57 & 3.08 \\
Synthetic lysine & 0.57 & 0.66 & 0.65 & 0.77 \\
Synthetic methionine & 0.13 & 0.20 & 0.16 & 0.25 \\
Synthetic tryptophan & 0.12 & 0.09 & 0.12 & 0.09 \\
Synthetic treonine & 0.24 & 0.26 & 0.26 & 0.29 \\
Monocalcium phosphate & 0.42 & 1.46 & 0.72 & 1.75 \\
Feed lime & 1.23 & 1.70 & 1.35 & 1.86 \\
Fine salt & 0.18 & 0.33 & 0.27 & 0.48 \\
Premix & 0.50 & 0.50 & 0.50 & 0.50 \\
\hline
\end{tabular}

"MP - Milk powder; ${ }^{* *}$ FM - Fish meal; ${ }^{* * *}$ HPS - High-protein soyabean oil-cake meal

Table 2 Digestible nutrient composition of experimental diets (calculated on an air-dry basis)

\begin{tabular}{lccccc}
\hline Nutrient & $\begin{array}{c}\text { Unit of } \\
\text { measure }\end{array}$ & $\begin{array}{c}\text { MP* } \\
\text { FM** }\end{array}$ & $\begin{array}{c}\text { MP + } \\
\text { HPS *** }\end{array}$ & HPS + FM & HPS \\
\hline $\begin{array}{l}\text { Crude protein } \\
\text { Lysine }\end{array}$ & $\%$ & 15.04 & 15.01 & 15.04 & 15.02 \\
Total sulphur containing & $\%$ & 1.28 & 1.28 & 1.28 & 1.28 \\
amino acids & $\%$ & 0.69 & 0.70 & 0.70 & 0.73 \\
Tryptophan & $\%$ & 0.25 & 0.25 & 0.25 & 0.25 \\
Threonine & $\%$ & 0.81 & 0.81 & 0.81 & 0.81 \\
DE (pig) & MJ/kg & 14.50 & 14.50 & 14.50 & 14.50 \\
Fat & $\%$ & 6.77 & 5.29 & 6.76 & 6.12 \\
Fibre & $\%$ & 2.73 & 2.45 & 2.67 & 2.71 \\
Calcium & $\%$ & 1.05 & 1.06 & 1.07 & 1.04 \\
Phosphorous & $\%$ & 0.44 & 0.45 & 0.43 & 0.41 \\
Sodium & $\%$ & 0.21 & 0.20 & 0.21 & 0.20 \\
Chloride & $\%$ & 0.37 & 0.35 & 0.35 & 0.33 \\
${ }^{*}$ MP - Milk powder ${ }^{* *}$ FM - Fish meal $;{ }^{* * *}$ HPS - High-protein soyabean oil-cake meal &
\end{tabular}

Diets were formulated according to digestible amino acids using the ideal amino acid pattern described by Kemm et al. (1990) (Table 2). Piglets were kept in pairs (i.e. a boar together with a gilt) in flat-deck type cages (1.5 x $1.0 \mathrm{~m})$ with perforated metal floors, self feeders and automatic water nipples. Animals were weighed weekly. Feed was supplied $a d$ libitum using self-feeders, and residues were weighed back weekly for determination of feed intake. Average daily gains (ADG) and feed conversion ratios (FCR) were calculated. Average daily gain was estimated by fitting a linear model $\left(\mathrm{R}^{2}\right.$ $>0.92$ ) to live mass data. The slope of this curve represents the ADG which was used for further data analysis. 
Five piglets per treatment were slaughtered at the end of the trial ( 8 weeks of age). The small intestine was removed following slaughter, placed in physiological saline solution and the mesenteric web was cut, allowing the intestine to be unfolded. Samples were taken at the terminal duodenum, mid-jejunum and distal jejunum (i.e. at points corresponding to $25 \%, 50 \%$ and $75 \%$ of the length of the small intestine) (Dunsford et al., 1989; Healy et al., 1994). The piglets with masses closest to the mean mass were selected for slaughter. Gender was not taken into consideration and only typical pigs were used in order to avoid selection of either exceptionally small or large piglets. Villus height and lamina propria depth was determined by means of interactive image analysis as described by Dunsford et al. (1989). The mean of ten villus height and ten lamina propria depth measurements were recorded from each of three cross-sections made per sample. Data was analysed by analysis of variance (Genstat 5,1993$)$.

\section{Results and discussion}

Average daily gain (ADG) did not differ $(p>0.05$ ) between sexes (boars: $376 \mathrm{~g} / \mathrm{d}$; gilts: $354 \mathrm{~g} / \mathrm{d}$ ) or treatments (Table 3). Li et al. (1991), however, found that pigs fed diets containing soyabean meal had a lower rate of gain. The absence of treatment differences in the current trial may be attributed to the fact that diets were formulated on a digestible amino acid basis. Presumably, that had not been the case in the study of Li et al. (1991). Total intake was measured per pen and did not differ $(p>0.05)$ between treatments. This could be of significance, as gut morphology is negatively influenced by reduced feed intake (Nunez et al., 1996; Pluske et al., 1996; Van Beers-Schreurs et al., 1998). As intake did not differ between treatments $(p>0.05)$ it was assumed that intake did not influence villus height. Feed conversion ratios did not differ $(p>0.05)$ between treatments, confirming the results obtained by Zhang et al. (1985). FCR tended to differ $(p=0.059)$ between the MP + HPS and HPS diets. This might be due to differences between the estimated and true digestible energy values of raw materials used in the diets.

Table 3 Average daily gain (ADG), feed conversion ratio (FCR) and total intake ( \pm standard deviation) from 4-8 weeks of age in piglets fed diets containing different protein sources.

\begin{tabular}{lccc}
\hline \multicolumn{1}{c}{ Treatment } & $\begin{array}{c}\text { ADG } \\
(\mathrm{g} / \text { day })\end{array}$ & $\begin{array}{c}\text { FCR } \\
(\mathrm{kg} \text { feed/kg gain })\end{array}$ & $\begin{array}{c}\text { Total intake } \\
(\mathrm{kg})\end{array}$ \\
\hline${\text { MP* }+\mathrm{FM}^{* *}}^{\text {MP }+ \text { HPS }}{ }^{* * *}$ & $353 \pm 102$ & $1.56 \pm 0.05$ & $30.63 \pm 4.10$ \\
HPS + FM & $349 \pm 106$ & $1.61 \pm 0.09$ & $31.48 \pm 7.44$ \\
HPS & $370 \pm 106$ & $1.58 \pm 0.13$ & $32.08 \pm 6.61$ \\
${ }^{*}$ MP - Milk powder; ${ }^{* *}$ FM - Fish meal; ${ }^{* * *}$ HPS - High-protein soyabean oil-cake meal
\end{tabular}

Villus height differed significantly $(p<0.05)$ between the terminal duodenum and the other areas of sampling, but no significant differences were observed between treatments (Table 4). These results are in contradiction to that of Dunsford et al. (1989) and Li et al. (1991) who found that villus height was decreased by high concentrations of soyabean meal. This could be attributed to a number of factors including differences in the age of piglets at sampling, the use of digestibility values for diet formulation in the present trial or differences in anti-nutritional factor content of the soyabean oil-cake meal used.

Table 4 Villus height $(\mathrm{mm}, \pm$ standard deviation) measured at different anatomical sites in the small intestine of piglets fed diets containing different protein sources.

\begin{tabular}{lccc}
\hline \multicolumn{1}{c}{ Treatment } & Terminal duodenum & Mid-jejunum & Distal jejunum \\
\hline MP* $^{*}$ FM $^{* *}$ & $1.846 \pm 0.37$ & $1.670 \pm 0.20$ & $1.516 \pm 0.19$ \\
MP + HPS*** & $1.804 \pm 0.28$ & $1.498 \pm 0.35$ & $1.416 \pm 0.16$ \\
HPS + FM & $1.744 \pm 0.27$ & $1.608 \pm 0.35$ & $1.472 \pm 0.29$ \\
HPS & $1.598 \pm 0.19$ & $1.432 \pm 0.14$ & $1.376 \pm 0.20$ \\
${ }^{*}$ MP - Milk powder; ${ }^{* *}$ FM - Fish meal; ${ }^{* * *}$ HPS - High-protein soyabean oil-cake meal
\end{tabular}

\section{Conclusion}

It was concluded that HPS can be utilised successfully in combination with other protein sources or as the main protein source in diets for weaner pigs without detrimental effects on either production parameters or gut histology. This may only be valid for diets formulated on the basis of digestible amino acids and for soyabean oil-cake meal that has been 
correctly processed.

\section{Acknowledgements}

Appreciation is expressed to ARC - ANPI and NOPO for the funding of the project.

\section{References}

Aherne, F.X. \& Nielsen, H.E., 1982. Lysine requirement of pigs weighing 7 to $19 \mathrm{~kg}$ live mass. Can. J. Anim. Sci. 63, 221-224.

Campbell, R.G. \& Dunkin, A.C., 1983. The influence of dietary protein and energy intake on the performance, body composition and energy utilisation of pigs growing from 7 to $19 \mathrm{~kg}$. Anim. Prod. 36, 185-192.

Campbell, R.G. \& Taverner, M.R., 1986. A note on the response of pigs weaned at 28 days to dietary protein. Anim. Prod. 42, 427-442.

Campbell, R.G., Taverner, M.R. \& Rayner, C.J., 1988. The tissue and dietary protein and amino acid requirements of pigs from 8 to $20 \mathrm{~kg}$ live mass. Anim. Prod. 46, 283-290.

Dunsford, B.R., Knabe, D.A. \& Haensly, W.E., 1989. Effect of dietary soyabean oil-cake meal on the microscopic anatomy of the small intestine in the early-weaned pig. J. Anim. Sci. 67, 1855-1863.

Fan, M.Z. Sauer, W.C. \& De Lange, C.F.M., 1995. Amino acid digestibility in soya bean meal, extruded soyabean and full-fat canola for early-weaned pigs. Anim. Feed Sci. and Technol. 52, 189-203.

Genstat 5, 1993. Genstat 5 committee of the statistical department IACF - Rothamsted U.K., 1995. GENSTAT 5 Reference Manual Clarendon press: Oxford.

Healy, B.J., Hancock, J.D., Kenney, G.A., Bramel-Cox, P.J., Behnke, K.C. \& Hines, R.H., 1994. Optimum particle size of corn and hard and soft sorghum for nursery pigs. J. Anim. Sci. 72, 2227-2236.

Huisman, J. \& Jansman, A.J.M., 1991. Dietary effects and some analytical aspects of anti nutritional factors in peas (Pisum sativum), common beans (Phaseolus vulgaris) and soyabeans (Glycine max L.) in monogastric farm animals. A literature review. Nutr. Abstr. Rev. 61, 901-921.

Kemm, E.H., Siebrits, F.K. \& Barnes, Penelope M., 1990. A note on the effect of dietary protein concentration, sex, type and live mass on whole-body amino acid composition of the growing pig. Anim. Prod; 51: 631-634.

Leibholz, J., 1985a. The digestion of protein in young pigs and the utilisation of dietary methionine. Brit. J. Nutr. 53, 137-147.

Leibholz, J., 1985b. An evaluation of total and digestible lysine as a predictor of lysine availability in protein concentrates for young pigs. Brit. J. Nutr. 53, 615-624.

Leibholz, J., 1986. The utilisation of lysine by young pigs from nine protein concentrates compared with free lysine in young pigs fed ad lib. Brit. J. Nutr. 55, 179-186.

Li, D.F., Nelssen, J.L., Reddy, P.G., Blecha, F., Klemm, R.D., Gieting, D.W., Hancock, J.D., Allee, G.L. \& Goodband, R.D., 1991. Measuring suitability of soyabean products for early weaned pigs with immunological criteria. J. Anim. Sci. 69(8); 3299-3307.

Makkink, C.A., Negulescu, G.P., Guixin, Q. \& Verstegen, M.W.A., 1994. Effect of dietary protein source on feed intake, growth, pancreatic enzyme activities and jejenal morphology in newly-weaned piglets. Brit. J. Nutr. 72, 353-368.

Marty, B.J. \& Chavez, E.R., 1995. Ileal digestibilities and urinary losses of amino acids in pigs fed heat processed soyabean products. Livest. Prod. Sci. 43, 37-48.

Miller, B.G., James, P.S., Smith, M.W. \& Bourne, F.J., 1986. Effect of weaning on the capacity of pig intestinal villus to digest and absorb nutrients. J. Agric. Sci. 107;579.

Nunez, M.C., Bueno, J.D., Ayudarte, M.V., Almendros, A., Rios, A., Suarez, M.D. \& Gil, A., 1996. Dietary restriction induces biochemical and morphometric changes in the small intestine of nursing piglets. J. Nutr. 126(4); 933-944.

Pluske, J.R., Williams, I.H. \& Aherne, F.X., 1996. Maintenance of villus height and crypt depth in piglets by providing continuous nutrition after weaning. Anim. Sci. 62(1); 131-144.

Ravindran, V. \& Kornegay, E.T., 1993. Acidification of weaner Pig Diets: A Rev.. J. Sci. Fd. Agric. 62, 313-322.

Sauer, W.C. \& Ozimek, L., 1986. Digestibility of amino acids in swine: Results and their practical applications. A Review. Livest. Prod. Sci. 15, 368-388.

Seve, B., 1985. Physiological basis of nutrient supply to piglets. World Rev. Anim Prod. XXI, (2), 8-14.

Van Beers-Schreurs, H.M.G. , Nabuurs, M.J.A.; Vellenga, L., Kalsbeek Van Der Valk, H.J., Wensing, T. \& Breukink, H.J., 1998. Weaning and the weanling diet influence the villus height and crypt depth in the small intestine of pigs and alter the concentrations of short-chain fatty acids in the large intestine and blood. J. Nutr. 128(6); 947-953. 
(C) South African Society of Animal Science

Vellenga, L., Egberts, H.J.A., Wensing, T., Van Dijk, J.E., Mouwen, J.M.V.M. \& Breukink, H.J., 1992. Intestinal permeability in pigs during rotavirus infection. Am. J. Vet. Res. 53(7); 1180-1183.

Viljoen, J. \& Ras, M.N., 1989. A note on different ratios of lysine to digestible energy in diets of piglets weaned at three weeks of age. S. Afr. J. Anim. Sci. 19, 133-136.

Viljoen, J., Coetzee, S.E., Fick, J.C., Siebrits, F.K. \& Hayes, J.P., 1998a. The ileal amino acid digestibility of different protein sources for early weaned piglets. Livest. Prod. Sci. 54, 45-53.

Viljoen, J. 1998. Amino acid digestibility of feedstuffs for pigs. Ph.D. Thesis, University of Stellenbosch.

Viljoen, J., Ras, M.N., Hayes, J.P. \& Siebrits, F.K., 1998b. Apparent and true amino acid digestibilities of feedstuffs in pigs employing the total ileal content (tic) technique and the mobile nylon bag (mnbt) technique. Livest. Prod. Sci. 53; 205-215.

Walker, W.R., Morgan, G.L. \& Maxwell, C.V., 1986. Ileal cannulation in baby pigs with a simple T-cannula. J. Anim. Sci. 62; 407-411.

Wilson, R.H. \& Leibholz, J., 1981. Digestion in pigs between 7 and 35d of age. III. The digestion of nitrogen in pigs given milk and soya-bean proteins. Br. J. Nutr. 45; 337-346.

Zhang, Y., Partridge, I.G., Keal, H.D. \& Mitchell, K.G., 1985. Dietary amino acid balance and requirements for pigs weaned at three weeks of age. Anim. Prod. 38; 441-448.

Zijlstra, R.T., Whang, K.Y., Easter, R.A. \& Odle, J., 1996. Effect of feeding milk replacer to early weaned pigs on growth, body composition, and small intestinal morphology, compared with suckled littermates. J. Anim. Sci. 74(12); 2948-2959. 